\title{
KORELASI PARAMETER MORFOMETRIK, NISBAH KELAMIN DAN KOMPOSISI UKURAN IKAN PEDANG (Xiphias gladius L.) DI SAMUDERA HINDIA
}

\section{CORRELATION OF SOME MORPHOMETRIC PARAMETERS, SEX RATIO AND SIZE COMPOSITION OF SWORDFISH (Xiphias gladius L.) CAUGHT BY INDONESIA TUNA LONGLINE FLEET IN INDIAN OCEAN}

\author{
Bram Setyadji dan Budi Nugraha \\ Peneliti pada Loka Penelitian Perikanan Tuna-Denpasar \\ Teregistrasi I tanggal: 10 Maret 2014; Diterima setelah perbaikan tanggal: 19 November 2014; \\ Disetujui terbit tanggal: 24 November 2014 \\ Email: bram.setyadji@gmail.com
}

\begin{abstract}
ABSTRAK
Model pengkajian stok melalui data frekuensi panjang lebih banyak digunakan karena data tersebut paling banyak tersedia dan mudah didapatkan dibandingkan data pengukuran jaringan keras (sisik, otolith, sirip dan tulang belakang) dan tagging. Khusus untuk ikan pedang, data panjang yang tersedia sebagian besar tidak standar dikarenakan ikan pedang yang tertangkap langsung diproses di laut yang mana bagian kepala, sirip, isi perut dibuang. Oleh karena itu dibutuhkan persamaan empiris untuk konversi dari ukuran non-standar ke standar sehingga bisa digunakan sebagai basis data pengkajian stok yang berbasis data tersebut. Data primer merupakan hasil observasi laut selama kurun waktu Maret 2011 sampai dengan Desember 2013, sedangkan data sekunder merupakan data observasi ilmiah Loka Penelitian Perikanan Tuna periode 2005-2013. Hasil penelitian menunjukkan terdapat korelasi yang signifikan antara beberapa parameter morfometrik ikan pedang yang diukur yakni panjang dari pangkal sirip dada ke ujung lekukan tengah sirip ekor $(L J F L)$, panjang dari mata ke ujung lekukan tengah sirip ekor $(E F L)$ dan panjang dari ujung rahang bawah ke ujung lekukan tengah sirip ekor $(P F L)$ $\left(\mathrm{R}^{2}>0,97 ; \mathrm{P}<0,01\right)$, akan tetapi tidak ada perbedaan yang nyata antara morfometri ikan pedang dan jenis kelamin ( $E F L-L J F L, \mathrm{P}>0,05$ dan $P F L-L J F L, \mathrm{P}>0,05)$. Hubungan antara nisbah kelamin dengan panjang ikan signifikan (Nisbah Kelamin $=0,0175 \mathrm{LJFL}-3,1001 ; \mathrm{n}=6$, selang kelas $5 \mathrm{~cm} ; \mathrm{P}<0,01$ ) yang mana ikan pedang dengan ukuran lebih dari $260 \mathrm{~cm}$ adalah betina.
\end{abstract}

KATA KUNCI: Parameter morfometrik, nisbah kelamin, komposisi ukuran, ikan pedang, Samudera Hindia

\begin{abstract}
Stock assessment models using length frequency data are more frequently used by Indonesian scientist due to its availability and easily obtained rather than skeletal parts or tagging data. As for swordfish most of the data vailable are not in standard form because most of swordfish landed are usually dressed at sea with various ways, so the length measurement are possible done afterward. Therefore conversion among different length measurements is a necessity for assessment and management purposes. Primary data was collected from scientific observer program conducted between March 2011 and December 2013, while secondary data was obtained from 2005-2013. The results showed that the models are fit quite well for Lower Jaw Fork Length (LJFL), Eye Orbit Fork Length (EOFL) and Pectoral Fork Length $(P F L)\left(R^{2}>0.97 ; P<0.01\right)$ and there was no significant relationship between morphometric and sex (EFL-LJFL, $P>0.05$ and PFL-LJFL, $P>0.05$ ). Correlation between sex ratio and body size proved to be significant with nearly all of the swordfish $>260 \mathrm{~cm}$ was female.
\end{abstract}

KEYWORDS: Morphometric parameters, sex ratio, size composition, swordfish, Indian Ocean

\section{PENDAHULUAN}

Ikan berparuh (Istioporidae dan Xiphiidae) merupakan komoditas perikanan kedua terbesar setelah tuna (Cramer et al., 1998), dan hampir $90 \%$ yang di daratkan di dunia merupakan hasil tangkap sampingan dari perikanan rawai tuna (Prager et al., 1995; Amande et al., 2008, 2010; Chapman, 2001; Cramer \&Adams, 1999; Campbell \& Tuck, 1998). Ikan pedang (Xiphias gladius) merupakan satu- satunya spesies dari famili Xiphiidae telah menjadi obyek eksploitasi di Samudera Pasifik (Brodziak \& Ishimura, 2010), Atlantik, dan Laut Mediterania (Tserpes \& Tsimenides, 1995). Sedangkan di Samudera Hindia, eksploitasi ikan pedang, dimulai sejak tahun 1950-an oleh armada Jepang dan didominasi oleh armada Taiwan pada tahun 1990-an (IOTC, 2009). Hasil tangkapan ikan pedang di Samudera Hindia terus meningkat, dari kurang 10.000 ton pada awal tahun 1990 dan mencapai puncaknya pada 
tahun 1998, yakni 35.000 ton (Wang \& Nishida, 2010). Kontribusi ikan pedang terhadap perikanan tuna di Indonesia cukup signifikan, di mana pada kurun waktu 2004-2007 rata - rata produksi mencapai 1.600 ton (Mahiswara \& Prisantoso, 2009). Status perikanan ikan pedang di IOTC (Indian Ocean Tuna Commission) menunjukkan bahwa tingkat pemanfaatan sudah mencapai padat tangkap (fully exploited), mendekati nilai maksimum tangkapan lestarinya (MSY) yakni 35.000 ton (IOTC, 2009).

Manajemen pengelolaan ikan pedang diatur oleh IOTC karena merupakan jenis ikan peruaya jauh dengan tipe stok tunggal sehingga pemanfaatannya harus dilakukan secara bersama-sama dengan negara lainnya di wilayah Samudera Hindia. Kajian stok ikan pedang dapat dilakukan dengan berbagai pendekatan, salah satunya adalah menggunakan informasi aspek morfometrik, seperti data frekuensi panjang ikan tertangkap, dapat digunakan sebagai dasar manajemen pengelolaan perikanan (Herrera \& Pierre, 2011; Neilson et al., 2006). Metode atau model yang berbasis dari data tersebut adalah FISAT (Gayanilo et al., 2005), COMPLEAT ELEFAN (Gayanilo \& Pauly, 1989), dan LFSA (Sparre \& Venema, 1999). Data frekuensi panjang dipilih karena data tersebut paling mudah didapatkan dibandingkan data pengukuran jaringan keras (sisik, otolith, sirip dan tulang belakang) maupun tagging.

Pada ikan berparuh, khususnya ikan pedang, untuk memperoleh data frekuensi panjang relatif sulit karena hasil tangkapan langsung diproses di laut, yaitu kepala, sirip, isi perut dibuang sehingga pengukuran hanya dapat dilakukan mulai dari panjang dari pangkal sirip dada ke ujung lekukan tengah sirip ekor (Pectoral Fork Length) sedangkan ukuran standar yang digunakan dalam kajian stok sesuai standarisasi IOTC adalah panjang dari ujung rahang bawah ke ujung lekukan tengah sirip ekor (Lower Jaw Fork Length). Perbedaan pengukuran ini akan menimbulkan interpretasi data yang berbeda antara panjang utuh dengan panjang setelah diproses, sehingga dibutuhkan persamaan empiris untuk konversi ukuran diantaranya (Prager et al., 1995).

Beberapa penelitian mengenai aspek morfometrik yakni korelasi antar ukuran panjang dari ikan berparuh telah dikemukakan oleh beberapa penulis, yang sebagian besar berbasis di Samudera Pasifik dan Atlantik, seperti Uchiyama \& Kazama (2003) dan Su et al. (2005) di perairan pesisir dan lepas pantai Taiwan. Lenarz \& Nakamura (1974) memberikan estimasi beberapa persamaan konversi untuk 3 spesies dari ikan berparuh. Prince \& Lee (1989) memberikan persamaan untuk estimasi konversi beberapa jenis pengukuran untuk ikan berparuh dari Samudera Atlantik, sedangkan Lee \& Prince (1990) memberikan persamaan empiris untuk konversi dari ukuran standar ke panjang total dan sebaliknya. Informasi yang berasal Samudera Hindia sejauh ini berasal dari IOTC (IOTC, 2009) dengan mengutip beberapa publikasi di atas, sedangkan literatur yang berasal dari Samudera Hindia masih belum tersedia sehingga penelitian ini penting untuk dilakukan.

Makalah ini bertujuan untuk mengetahui hubungan beberapa parameter morfometrik (LJFL, EFL, dan PFL), nisbah kelamin dan komposisi ukuran ikan pedang (Xiphias gladius) yang dapat digunakan sebagai basis data dalam mengisi ketiadaan informasi perikanan jenis ini pada pengelolaan perikanan regional.

\section{BAHANDANMETODE}

Penelitian dilakukan dari bulan Maret 2011 sampai dengan Desember 2013, daerah penelitian adalah perairan Samudera Hindia, dengan koordinat antara $10^{\circ}-35^{\circ} \mathrm{LS}$ dan $75^{\circ}-125^{\circ} \mathrm{BT}$ (Gambar. 1). Sebagian besar lokasi berada di sebelah selatan lintang $13^{\circ} \mathrm{LS}$, yang merupakan perairan laut bebas karena sudah di luar Zona Ekonomi Esklusif (ZEE) Indonesia. Spesimen ikan pedang yang digunakan untuk penelitian diperoleh dari hasil tangkapan kapalkapal rawai tuna Indonesia yang berbasis di Pelabuhan Benoa oleh pemantau ilmiah yang berasal dari Loka Penelitian Perikanan Tuna.

Spesimen diidentifikasi, dicatat jenis kelaminnya dan diukur panjangnya dengan tiga jenis pengukuran yakni: 1) panjang dari ujung rahang bawah ke ujung lekukan tengah sirip ekor (LJFL); 2) panjang dari mata ke ujung lekukan tengah sirip ekor (EFL); 3) dan panjang dari pangkal sirip dada ke ujung lekukan tengah sirip ekor (PFL) (Gambar. 2). Data ukuran panjang dalam penelitian ini diambil dengan cara merentangkan pita pengukur di sepanjang tubuh ikan (pengukuran melengkung), sedangkan cara pengambilan ukuran panjang di darat biasanya dilakukan secara tegak lurus dengan menggunakan alat ukur yang sifatnya kaku (rigid), seperti: kaliper (pengukuran lurus). Data nisbah kelamin dan komposisi ukuran diperoleh dari analisa data pemantau ilmiah Loka Penelitian Perikanan Tuna mulai tahun 2005 sampai dengan 2013.

Konversi antar ukuran panjang dianalisis dengan persamaan model Ordinary Least Square (OLS) untuk mendapatkan model regresi linear sederhana yang sesuai (Morato et al., 2001) yakni: $L J F L=a \times(E F L / P F L)+b$, dimana $a$ dan $b$ adalah parameter yang dicari. Model dibedakan menurut jenis kelamin, yakni jantan dan betina. Untuk menguji signifikansi antar jenis kelamin digunakan uji $t$-student untuk membandingkan slope pada 2 sampel independen (Zar, 1996 dalam Morato et al., 2001). Apabila tidak ada signifikansi antar keduanya, data korelasi antara LJFL, EFL dan PFL dihitung kembali untuk mendapatkan persamaan regresi linear campuran (pooled sex). Signifikansi model regresi diuji dengan Analysis of Variance (ANOVA) dengan hipotesis $\mathrm{H}_{0}$ : $\mathrm{a}=0$ dan $\mathrm{H}_{1}$ : $\hat{\mathrm{a}}$ “"“o 


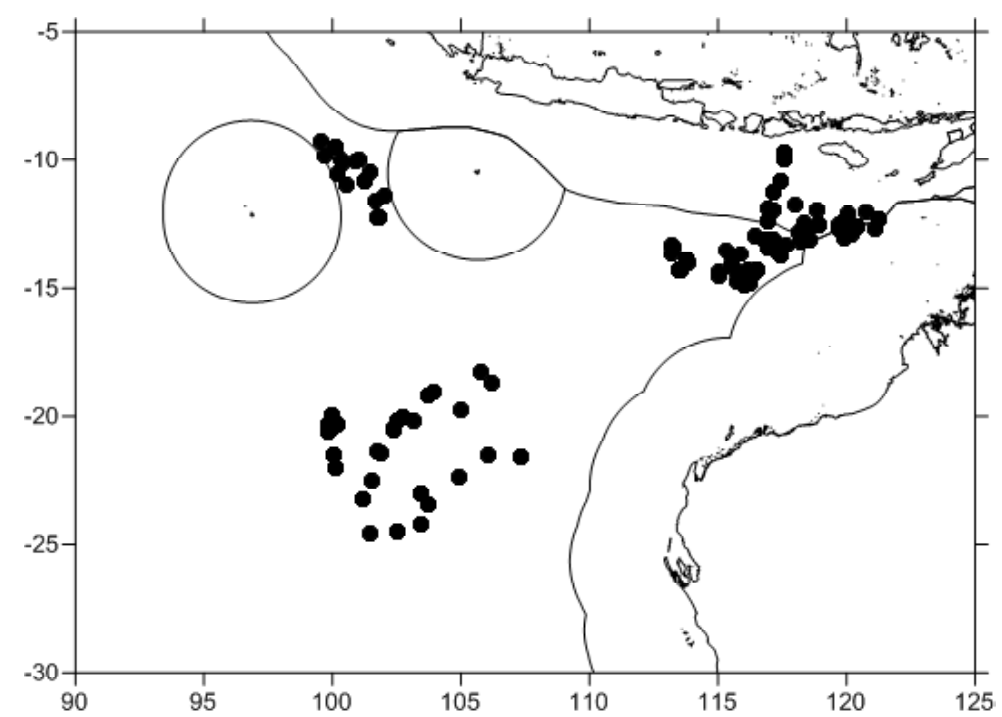

Gambar 1. Peta daerah penelitian ikan pedang di Samudera Hindia.

Keterangan: bulatan hitam menunjukkan lokasi penangkapan ikan pedang sedangkan garis tipis di luar batas negara merupakan Zona Ekonomi Esklusif (ZEE).

Figure 1. Map showing research area for swordfish in Indian Ocean..

Remarks: black dots show the fishing ground and the thin lines around the country border is Exclusive Economy Zone

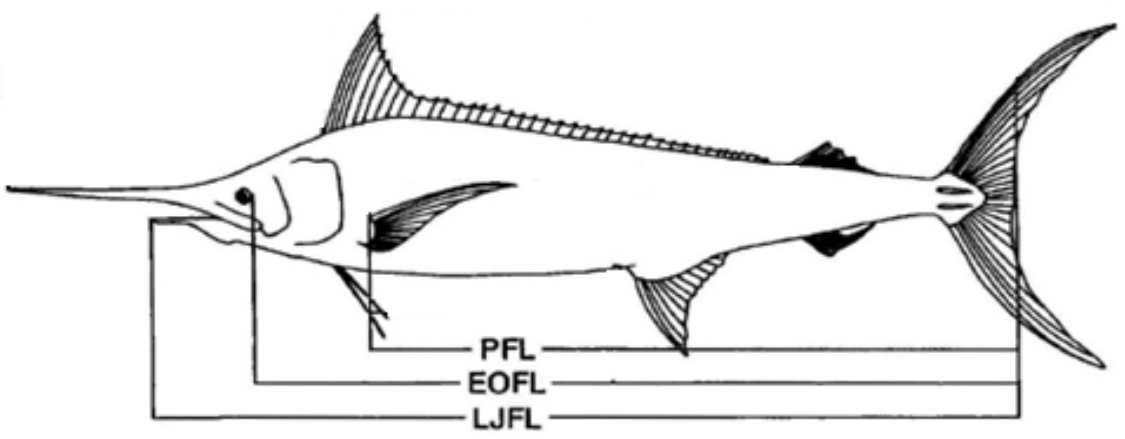

Gambar 2. Jenis-jenis pengukuran panjang yang dilakukan selama penelitian.

Picture 2. Various length measurement conducted during research.

Keterangan:

PFL : Pectoral Fork Length (panjang dari pangkal sirip dada ke ujung lekukan tengah sirip ekor)

EFL : Eye-Fork Length (panjang dari mata ke ujung lekukan tengah sirip ekor)

LJFL : Lower Jaw-Fork Length (panjang dari ujung rahang bawah ke ujung lekukan tengah sirip ekor)

Sumber: Poisson \& Taquet (2001)

(Zar, 1996 dalam Morato et al., 2001) menggunakan software Minitab® release 14.12.0. Hasil regresi kemudian digunakan untuk mengonversikan data panjang nonstandar ke panjang standar berdasarkan jenis kelamin dari data observasi tahun 2005-2013.

Analisa nisbah kelamin berdasarkan selang kelas panjang $(5 \mathrm{~cm})$ digambarkan dengan proporsi jumlah ikan pedang betina yang tertangkap terhadap keseluruhan jumlah ikan jantan dan betina. Proporsi betina diasumsikan $100 \%$ (nisbah kelamin =1) pada ukuran lebih dari $230 \mathrm{~cm}$. Fluktuasi proporsi betina dengan ukuran di bawah $200 \mathrm{~cm}$ sangat bervariasi sehingga diasumsikan nilai nisbah kelamin 0,5 (1:1). Analisis regresi digunakan untuk menentukan proporsi betina ikan pedang dengan selang kelas $5 \mathrm{~cm}$ pada ukuran 200 - $230 \mathrm{~cm}$ LJFL.

\section{HASIL DAN BAHASAN}

\section{HASIL}

Total terdapat 110 spesimen ikan pedang dari 10 trip observasi laut selama kurun waktu bulan Maret 2011 sampai dengan Desember 2013. Komposisi spesimen 
Tabel 1. Ukuran morfometrik berdasarkan panjang minimum dan maksimum, rata-rata panjang serta jenis kelamin spesimen ikan pedang yang tertangkap oleh armada rawai tuna di Samudera Hindia selama bulan Maret 2011 - Desember 2013

Table 1. Morphometric measurement based on maximum and minimum length, average length and sex of swordfish caught by longliners in Indian Ocean from March 2011 to December 2013

\begin{tabular}{llrrr}
\hline & Jenis kelamin/Sex & LJFL & EFL & PFL \\
\hline \multirow{3}{*}{ Mininum } & Jantan & 58,0 & 48,0 & 40,0 \\
& Betina & 84,0 & 75,0 & 61,0 \\
& Tak teridentifikasi & 58,0 & 48,0 & 40,0 \\
\multirow{3}{*}{ Maksimum } & Jantan & 254,0 & 230,0 & 190,0 \\
& Betina & 252,0 & 232,0 & 197,0 \\
& Tak teridentifikasi & 254,0 & 232,0 & 197,0 \\
\multirow{3}{*}{ Rata-rata } & Jantan & 160,1 & 140,4 & 119,1 \\
& Betina & 174,4 & 157,7 & 127,4 \\
& Tak teridentifikasi & 149,1 & 132,2 & 110,3 \\
\hline
\end{tabular}

Tabel 2. Persamaan regresi linear antara ukuran parameter morfometrik ikan pedang yang tertangkap oleh armada rawai tuna di Samudera Hindia selama bulan Maret 2011 - Desember 2013

Table 2. Linear regression equations among morphometric parameters of swordfish caught by longliners in Indian Ocean from March 2011 to December 2013

\begin{tabular}{|c|c|c|c|c|c|}
\hline Jenis kelamin/Sex & Persamaan Regresi Linear/Equation of linier regrestion & $\mathbf{r}^{2}$ & $\mathbf{n}$ & a & b \\
\hline \multirow[t]{2}{*}{ Jantan } & $\mathrm{LJFL}=a+b \mathrm{EFL}$ & 0,9977 & 18 & 9.6893 & 1.0715 \\
\hline & $\mathrm{LJFL}=a+b \mathrm{PFL}$ & 0,9902 & 18 & 13.6330 & 1.2303 \\
\hline \multirow[t]{2}{*}{ Betina } & $\mathrm{LJFL}=a+b \mathrm{EFL}$ & 0,9962 & 14 & 8.2448 & 1.0537 \\
\hline & $\mathrm{LJFL}=a+b \mathrm{PFL}$ & 0,9834 & 14 & 12.6690 & 1.2701 \\
\hline \multirow[t]{2}{*}{ Campur } & $\mathrm{LJFL}=a+b \mathrm{EFL}$ & 0,9884 & 129 & 12.2160 & 1.0354 \\
\hline & $\mathrm{LJFL}=a+b \mathrm{PFL}$ & 0,9705 & 129 & 14.0030 & 1.2242 \\
\hline
\end{tabular}

terdiri dari 18 jantan, 14 betina dan 78 yang tak teridentifikasi jenis kelaminnya dikarenakan gonad belum dapat dikenali maupun kendala di lapangan. Kisaran panjang spesimen jantan antara 58-254 cm dengan ratarata $160,1 \mathrm{~cm}$, betina antara $84-252 \mathrm{~cm}$ dengan rata-rata $174,4 \mathrm{~cm}$ (Tabel 1. dan Gambar. 3).

Persamaan regresi linear antara $L J F L, E F L$, dan $P F L$ ikan pedang jantan, betina, dan yang tidak teridentifikasi jenis kelaminnya signifikan (ANOVA, $\mathrm{P}<0,01$ ) dengan nilai $\mathrm{R}^{2}$ lebih besar dari 0.97 (Tabel. 2), yang menunjukkan bahwa persamaan ini mempunyai tingkat keyakinan yang tinggi (robust) dengan nilai galat yang rendah. Hasil uji $t$ student terhadap korelasi antara ikan pedang jantan dan betina menunjukkan bahwa tidak terdapat perbedaan antar parameter morfometrik (EFL-LJFL, P >0,05 dan PFL-LJFL, $\mathrm{P}>0,05)$.

Panjang pertama kali matang gonad ikan pedang menurut IOTC (2009) adalah $170 \mathrm{~cm}$. Berdasarkan data tersebut maka hasil sebaran frekuensi panjang pada kurun waktu 2005 - 2013 menunjukkan bahwa 37,18\% jantan dan $22,18 \%$ betina sudah berada pada ukuran pertama kali matang gonad, sedangkan secara keseluruhan hanya $30 \%$ dari ikan pedang yang tertangkap sudah matang secara seksual. Perbandingan nisbah kelamin betina dan jantan adalah 1:1.16, hasil uji Chi-Square menyatakan bahwa perbandingan antar keduanya tidak berbeda nyata dimana nilai $X^{2}$ hitung $(0,18)<$ dari nilai $X^{2}(3,84 ; a ́=0,05 ; d b=1)$. Sehingga bisa dianggap bahwa nisbah kelamin betina dan jantan adalah 1:1. Nilai nisbah kelamin berfluktuasi seiring dengan bertambahnya ukuran panjang dengan pola yang tidak signifikan pada ukuran di bawah $200 \mathrm{~cm}$ (Gambar. 4). Nisbah kelamin mulai meningkat pada ukuran di atas $205 \mathrm{~cm}$, dan semua spesimen adalah betina (nilai nisbah kelamin =1) pada ukuran lebih dari $260 \mathrm{~cm}$. Hubungan antara nisbah kelamin (proporsi betina terhadap total) dengan panjang ikan pedang ditunjukkan oleh persamaan regresi linear:

Nisbah Kelamin $=0,0175$ LJFL $-3,1001$

$\left(\mathrm{R}^{2}=0,7834 ; \mathrm{n}=7\right.$, selang kelas $\left.5 \mathrm{~cm} ; \mathrm{P}<0,01\right)$ 


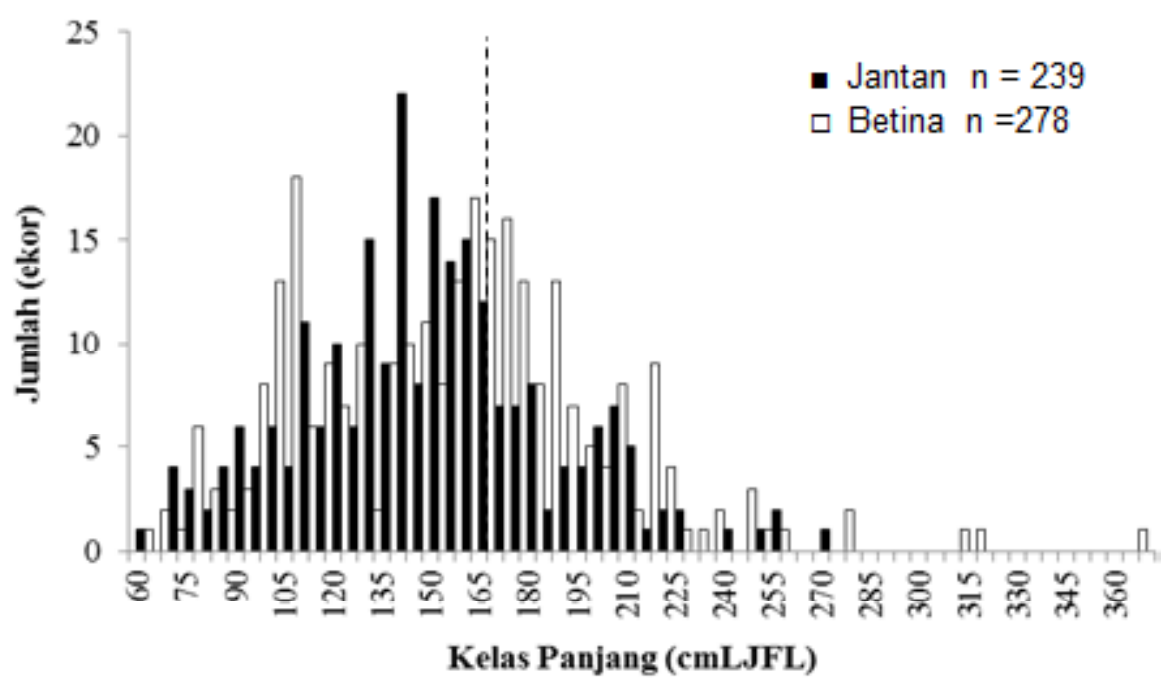

Gambar 3. Sebaran frekuensi panjang ikan pedang yang tertangkap oleh armada rawai tuna di Samudera Hindia pada kurun waktu 2005 - 2013, garis putus-putus menunjukkan ukuran pertama kali matang gonad $170 \mathrm{~cm}$ (IOTC, 2009).

Picture 3. Length frequency distribution of swordfish caught by longliners in Indian Ocean from 2005 to 2013 , dotted lines show the length at first maturity $170 \mathrm{~cm}$ (IOTC, 2009).

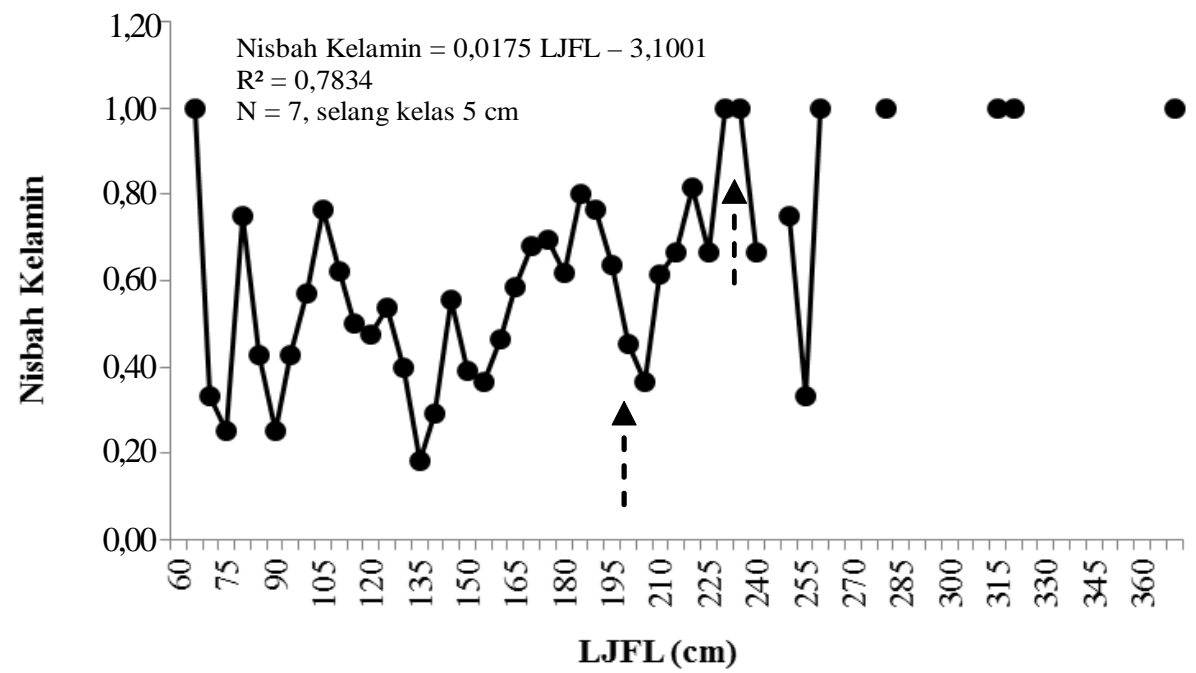

Gambar 4. Estimasi hubungan antara nisbah kelamin (betina/total) dengan LJFL (selang kelas $5 \mathrm{~cm}$ ) dari hasil tangkapan rawai tuna di Samudera Hindia periode 2005 - 2013. Tanda panah menunjukkan batasan selang kelas $(200 \leq \mathrm{LJFL} \leq 230)$ yang digunakan untuk analisa regresi proporsi betina terhadap panjang ikan.

Picture 4. Estimation on relationship between sex ratio (female/total) and LJFL (interval class $5 \mathrm{~cm}$ ) of swordfish caught by longliners in Indian Ocean from 2005 to 2013. The arrow marks show the limit of interval class used for regression analysis for female proportion to length (200 $\leq L J F L \leq 230)$.

\section{BAHASAN}

Ikan berparuh mempunyai tubuh yang ramping dan panjang sehingga perbedaan pengukuran yang digunakan dalam metode ini sangat kecil (Praeger et al., 1995). Hal ini dibuktikan oleh Lee \& Scott (1992) dimana estimasi parameter persamaan konversi ukuran panjang untuk ikan pedang berdasarkan pengukuran melengkung tidak berbeda secara signifikan $(\mathrm{P}<0,05)$ dengan pengukuran lurus.
Aspek morfometrik dipengaruhi oleh morfologi ikan, beberapa penelitian melaporkan adanya dimorfisme seksual pada ikan pedang (DeMartini et al., 2007; Sun et al., 2002) dan ikan jantan tumbuh lebih lambat dari betina serta mencapai panjang asimtotik yang lebih rendah daripada betina (FAO, 2013). Pada penelitian ini, hasil persamaan regresi linear menunjukkan bahwa hubungan antara beberapa parameter morfometrik dengan jenis kelamin tidak signifikan, hal ini diduga karena ikan pedang mempunyai tubuh ramping dan panjang, berbeda dengan 
jenis tuna mata besar ataupun sirip biru selatan dimana ketika dewasa, bentuk tubuh betina lebih besar dan gempal daripada jantan. Sehingga walaupun terdapat fenomena dimorfisme akan tetapi hal tersebut tidak berpengaruh pada aspek morfometrinya. Hal yang sama juga disampaikan oleh Su et al. (2005) di perairan lepas pantai Taiwan.

Tidak adanya signifikansi hubungan morfometrik dengan jenis kelamin menunjukkan bahwa aplikasi konversi untuk ikan pedang yang tidak teridentifikasi (pooled sex) dapat digunakan secara keseluruhan pada semua jenis kelamin. Hal ini akan memudahkan peneliti dalam rangka pengambilan data, terutama apabila menemukan kondisi di mana jenis kelamin tidak dapat diidentifikasi atau diketahui. Data tersebut juga dapat digunakan untuk mengonversi dari data-data panjang sebelumnya yang didapatkan dalam berbagai macam ukuran yang tidak standar, seperti halnya data frekuensi panjang hasil dari pengamatan di tempat-tempat pendaratan ikan. Semakin banyak data maka akan didapatkan data ukuran panjang dengan komposisi kisaran yang lebar yang mana akan berpengaruh terhadap validitas dari model itu sendiri, terutama terhadap model yang disajikan akan mewakili semua ukuran kelas panjang dan menghindari adanya underestimate maupun overestimate (Prager et al., 1995).

Rasio jantan dan betina pada penelitian-penelitian sebelumnya lebih tinggi daripada yang didapatkan pada penelitian ini. Nisbah kelamin ikan pedang yang tertangkap oleh armada rawai tuna di Hawaii sebesar 0,53 (DeMartini et al., 2000). Rasio ikan betina dengan jantan di lepas pantai selatan California sebesar 2.94: 1 (nisbah kelamin 0,75) (Weber \& Goldberg, 1986); 2.3: 1 (nisbah kelamin 0,70) untuk ikan pedang yang tertangkap oleh perikanan Kanada di Atlantik Utara sebelah barat (Stone \& Porter 1997); dan 2,25: 1 (nisbah kelamin 0,69) untuk ikan pedang yang tertangkap di Australia Selatan (ZEE Australia) (Young et al., 2000). Pada penelitian ini $70 \%$ ikan pedang yang tertangkap berada pada ukuran di bawah $170 \mathrm{~cm}$, dengan rasio betina dan jantan adalah 1:1.16 (278 betina dan 239 jantan, nisbah kelamin 0,54). Hasil uji Chi-Square menyatakan bahwa perbandingan antar keduanya tidak berbeda nyata dimana nilai $\mathrm{X}^{2}$ hitung $(0,18)<$ dari nilai $\mathrm{X}^{2}$ $(3,84 ; a ́=0,05 ; d b=1)$. Sehingga bisa dianggap bahwa nisbah kelamin betina dan jantan adalah 1:1. Hal ini dikarenakan ikan pedang yang tertangkap didominasi oleh kelas ukuran di bawah $170 \mathrm{~cm}$ maka tidak mengherankan bahwa nisbah kelamin adalah 1:1.

Hubungan antara nisbah kelamin dan ukuran badan (morfologi) dapat dijadikan dasar untuk merekonstruksi komposisi jenis kelamin dari data hasil tangkapan (Wang et al., 2000). Stone \& Porter (1997) menggunakan persamaan regresi linear untuk menggambarkan pola antara nisbah kelamin dan panjang untuk ikan pedang yang tertangkap oleh armada Kanada di Atlantik Utara sebelah barat, sedangkan DeMartini et al. (2000) menggunakan model yang berdasarkan fungsi power pada ikan pedang yang tertangkap oleh perikanan rawai yang berbasis di Hawaii.

\section{KESIMPULAN}

Terdapat korelasi yang erat antara ukuran morfometrik yakni $L J F L, E F L$, dan $P F L$ (ANOVA, P < 0,01), dengan nilai $\mathrm{R}^{2}$ lebih besar dari 0,97 dan tidak ada perbedaan yang nyata ukuran morfometrik jantan dan betina pada ikan pedang (EFL-LJFL, $\mathrm{P}>0,05$ dan PFL-LJFL, $\mathrm{P}>0,05)$. Hubungan antara nisbah kelamin dengan panjang ikan signifikan (Nisbah Kelamin =0,0175 LJFL - 3,1001; $\mathrm{n}=6$, selang kelas $5 \mathrm{~cm} ; \mathrm{P}<0,01$ ) yang mana ikan pedang dengan ukuran lebih dari $260 \mathrm{~cm}$ adalah betina.

\section{PERSANTUNAN}

Penulis mengucapkan terima kasih yang sebesar besarnya kepada pemantau ilmiah dari Loka Penelitian Perikanan Tuna yang telah bekerja keras mengumpulkan data selama penelitian dilangsungkan. Penghargaan juga diberikan kepada Commonwealth Scientific and Industrial Research Organisation (CSIRO), Australian Centre for International Agricultural Research (ACIAR) dan Pusat Penelitian Pengelolaan Perikanan dan Konservasi Sumber Daya Ikan (P4KSI) yang telah mendukung dan mendanai kolaborasi penelitian melalui program FIS/2002/074: Capacity Development to Monitor, Analyse and Report on Indonesian Tuna Fisheries.

\section{DAFTAR PUSTAKA}

Amandè, J.M., J. Ariz., E. Chassot., P. Chavance., D.M.A. Delgado., D. Gaertner., H. Murua., R. Pianet \& J. Ruiz. 2008. Bycatch and discards of the European purse seine tuna fishery in the Indian Ocean. Estimation and characteristic for the 2003-2007 period. Paper presented in Ecosystem and By-catch Working Group, 20 - 22 October 2008. Bangkok. Thailand. 26 p.

Amandè, M.J., C.E. Lennert-Cody., N. Bez., M. Hall \& A.C. Chassot. 2010. How much sampling coverage affects bycatch estimates in purse seine fisheries? IOTC2010-WPEB-20.16 p.

Brodziak, J \& G. Ishimura. 2010. Stock assessment of North Pacific swordfish (Xiphias gladius) in 2009. Pacific Islands Fish. Sci. Cent., Natl. Mar. Fish. Serv., NOAA, Honolulu, HI 96822-2396. Pacific Islands Fish. Sci. Cent. Admin. Rep. H-10-01. 37 p. 
Campbell, R.A\& G.N. Tuck. 1998. Preliminary analysis of billfish catch rates in the Indian Ocean. $7^{\text {th }}$ Expert Consultation on Indian Ocean, Victoria, Seychelles, 9-14 November 1998. $19 \mathrm{p}$.

Chapman, L. 2001. Bycatch in the tuna longline fishery. $2^{\text {nd }}$ SPC Heads of Fisheries Meeting (Noumea, New Caledonia, 23-27 July 2001).

Cramer, J. \& H.M. Adams. 1999. Pelagic longline bycatch. Col.Vol.Sci.Pap.ICCAT. 49 (4): 288-299.

Cramer, J., A. Bertolino \& G.P. Scott. 1998. Estimates of recent shark bycatch by U.S. vessels fishing for Atlantic tuna and tuna-like species. Col.Vol. Sci. Pap.ICCAT. 48 (3): 117-128.

DeMartini, EE., J.H. Uchiyama \& H.A. Williams. 2000. Sexual maturity, sex ratio, and size composition of swordfish, Xiphias gladius, caught by the Hawaiibased pelagic longline fishery. Fish. Bull. 98: 489-506.

DeMartini, E.E., J.H. Uchiyama., R.L. Humphreys Jr., J.D. Sampaga. \& H.A. Williams. 2007. Age and growth of swordfish (Xiphias gladius) caught by the Hawaiibased pelagic longline fishery. Fish. Bull. 105: 356367

FAO (Fisheries and Agricultural Organisation). 2013. Biological characteristics of tuna. http://www.fao.org/ fishery/topic/16082/en\#Characteristics. Diunduh pada tanggal 24 Februari 2013.

Gayanilo, F.C. \& D. Pauly. 1989. Announcing the release of Version 1.1 of the Complete ELEFAN Software package. Fishbyte. 7 (2): 20-21.

Gayanilo, F.C., P. Sparre. \& D. Pauly. 2005. FAO-ICLARM Stock Assessment Tools II (FISAT II). Revised version. User's guide. FAO Computerized Information Series (Fisheries) No. 8.

Herrera, M. \& L. Pierre. 2011. Preparation of data input files for the stock assesments of Indian Ocean swordfish. IOTC-2011-WPB09-07. 32 p.

IOTC (Indian Ocean Tuna Commission). 2009. Executive summary of the status of the Indian Ocean swordfish resource. IOTC-2009-SC-04[E].

Lee, D.W. \& E.D. Prince. 1990. Further development of length and weight regression parameters for Atlantic blue marlin, white marlin and sailfish. Col.Vol.Sci.Pap.ICCAT. 32 (2): 418-425.
Lee, D.W. \& G.P. Scott. 1992. Development of length and weight regression parameters for Atlantic swordfish (Xiphias gladius). Col.Vol.Sci.Pap.ICCAT. 39 (2): 572578.

Lenarz, W.H. \& E.L. Nakamura. 1974. Analysis of length and weight data on three species of billfish from the western Atlantic Ocean dalam Shomura, R.S. \& F. Williams, eds. Proceedings of the International Billfish Symposium, Kailua-Kona, Hawaii, 9-12 Agustus 1972. Part 2: Review and contributed papers. U.S. Dept. Commer. NOAA Tech. Rep. NMFS SSRF675.

Mahiswara \& B. I. Prisantoso. 2009. Billfish fisheries in Indonesia. IOTC-2009-WPB-14. $10 \mathrm{pp.}$

Morato, T., P. Alfonso., P. Lourinho., J.P. Barreiros., R.S. Santos. \& R.D.M. Nash. 2001. Length-weight relationship for 21 coastal fish species of the Azores, north-eastern Atlantic. Fisheries Research. 50 (2001): 297-302.

Neilson, J.D., S.D. Paul. \& S.C. Smith. 2006. Stock structure of swordfish (Xiphias gladius) in the Atlantic: A review of the non-genetic evidence. Col.Vol.Sci.Pap.ICCAT. $61: 25-60$

Poisson, F \& M. Taquet. 2001. Country report reunion swordfish fishery (France). WPB01-07. IOTC Proceedings 4: 144 -154

Prager, M.H., E.D. Prince. \& D.W. Lee. 1995. Empirical length and weight conversion equations for blue marlin, white marlin and sailfish from the north Atlantic Ocean. Bulletin of Marine Science. 56 (1): 201-210.

Prince, E.D. \& D.W. Lee. 1989. Development of length regressions for Atlantic Istiophoridae. Col.Vol.Sci.Pap.ICCAT. 30 (2): 364-374.

Su, N.J., C.L. Sun., S.Z. Yeh., W.C. Chiang., S.P. Wang \& C.H. Liu. 2005. LJFL and EFL relationship for the billfishes caught by the Taiwanese offshore and coastal fisheries. A working paper submitted to the 1st Joint Intercessional Meeting of the Swordfish and Marlin Working Group of ISC. 29 Agustus-2 September 2005.

Sun, C.L., S.P. Wang \& S.Z. Yeh. 2002. Age and growth of the swordfish (Xiphias gladius L.) in the waters around Taiwan determined from anal-fin rays. Fish. Bull. 100: 822-835.

Stone, H.H \& J.M. Porter. 1997. Development of a swordfish sex ratio-at-size relationship for catches from the 
Canadian fishery. Int. Comm. Conserv. Atl. Tunas Coll.Vol.Sci.Pap. 46: 311-314.

Tserpes, G. \& N. Tsimenides. 1995. Determination of age and growth of swordfish, Xiphias gladius L., 1758, in the Eastern Mediterranean using anal-fin spines. Fishery Bulletin. 93: 594-602.

Uchiyama, J.H. \& T.K. Kazama. 2003. Updated weight-onlength relationships for pelagic fishes caught in the Central North Pacific Ocean and bottomfishes from the Northwestern Hawaiian Islands. PIFSC Administrative Report $\mathrm{H}-03-01.46$ pp.

Wang, S.P \& T. Nishida. 2010. Update of the application of an age-structured assessment model to swordfish
(Xiphias gladius) in the Indian Ocean. IOTC-WPB2010-13.16 p.

Weber, E.C., \& S.R. Goldberg. 1986. The sex ratio and gonad indices of swordfish, Xiphias gladius, caught off the coast of southern California in 1978. Fish. Bull. 84: $185-186$.

Young, J., A. Drake., T. Carter. \& J. Farley. 2000. Reproductive dynamics of broadbill swordfish (Xiphias gladius) in the eastern Australian AFZ-preliminary results. $13^{\text {th }}$ Meeting of the Standing Committee on Tuna and Billfish, working paper, BBRG-12. July 5-12, 2000. Noumea, New Caledonia. Oceanic Fisheries Programme, Secretariat of the Pacific Committee, Noumea, New Caledonia. $126 \mathrm{p}$. 